\title{
Kern-oorwegings in die besinning oor die rol van die (NG) Kerk in Suid- Afrika se grondhervormingsdebat
}

\author{
Van Niekerk, Anton A \\ Universiteit Stellenbosch, Stellenbosch, Suid-Afrika \\ aavn@sun.ac.za
}

\begin{abstract}
Core considerations in the reflection on the role of the (NG) Church in South Africa's land reform debate

This article deals with the question as to whether the church (the Dutch Reformed Church in particular) ought to become involved in the current (2019) debate about land reform (particularly land expropriation without compensation) in South Africa. The author defends the position that such involvement is, for the church, desirable and even unavoidable. Four key elements of such involvement are identified and analysed. The first is the issue of human dignity, which is a key aspect of the message of the gospel. The second aspect is (possible) leadership. Here it is argued that the church can facilitate, but not in a traditional leadership role. Much attention is, thirdly, paid to the moral aspects of the debate. Finally, in terms of the "how"-question relating to the church's involvement, dialogue is proposed.
\end{abstract}

Key words

Land debate; human dignity; morality; leadership; values; dialogue

Where justice is denied, where poverty is enforced, where ignorance prevails, and where one class is made to feel that society is an organized conspiracy to oppress, rob and degrade them, neither persons nor property will be safe. (Frederick Douglas) 


\section{Kontekstualisering}

Hierdie artikel is 'n verwerking van 'n referaat wat ek by 'n onlangse beraad oor Suid-Afrika se omstrede grondkwessie gelewer het. ${ }^{1}$ Die beraad is deur die NG Gemeentes Williston en Carnavon gereël. Dit is bygewoon deur 'n gehoor van ongeveer 60 mense, waarvan die meerderheid landbouprodusente (boere) was, aangevul deur 'n aantal predikante en enkele akademici (soos ekself). Die doel van die beraad was nie alleen om in die algemeen te besin oor die problematiek rondom grondhervorming in Suid-Afrika nie, maar veral om te besin oor die vraag of en hoe die kerk 'n rol kan speel in die fasilitering van die huidige gespanne debat oor hierdie aangeleentheid.

Grond en die (her-)verdeling daarvan is tans so 'n kontensieuse kwessie in Suid-Afrika dat dit'n ter sake vraag is of dit verstandig is vir die kerk om ook by die saak betrokke te raak. Ek meen van wel. Daar bestaan 'n wydlopende persepsie in Suid-Afrika, veral onder swart mense, dat laasgenoemde eintlik die enigste groep is wat daadwerklike offers moes bring om aan die gedemokratiseerde Suid-Afrika effektiewe beslag te gee. Terwyl die skikking van 1994 onontkenbare politieke regte aan alle Suid-Afrikaners besorg het, en hoewel dit so is dat die uitoefening van daardie regte regering deur die African National Congress (ANC) teweeggebring het - dié organisasie wat oorwegend deur swart Suid-Afrikaners as die vernaamste "bevrydingsbeweging" beskou word - is daar 'n groeiende onbehae onder swart mense oor hul volgehoue, onbevredigende sosio-ekonomiese posisie. Werkloosheid neem nie af nie; trouens, dit neem gestadig toe, en staan de facto op die oomblik op tussen $30 \%$ en $35 \%$. Terwyl dit wel so is dat die regering enorme investerings in onderwys en mediese dienste gemaak het (met tans weinig sigbare positiewe gevolge), en terwyl Suid-Afrika van die hoogste relatiewe vlakke van sosiaal-maatskaplike toelaes in ontwikkelende lande maandeliks aan armes en werkloses uitbetaal, bring die gebrek aan werk mee dat die begunstigdes van genoemde toelaes steeds groei en dat dit weinig effek het om die vlakke van armoede te verlaag. Hiermee gaan gepaard die amper ongebreidelde vorme van korrupsie, onbevoegdheid en wanbesteding in en van owerheidsbronne oor die afgelope dekade.

1 Die beraad het plaasgevind te Williston in die Noord-Kaap op 18 en 19 Maart 2019. 
Dit alles het meegebring dat die aandrang op grondhervorming, wat sedert 1994 op die agenda van die regering en regerende party is, in die loop van veral 2018 nuwe impetus gekry het. Die teikens van hierdie grondhervormingsbeleid (byvoorbeeld dat 30\% van die landbougrond binne 20 jaar na onafhanklikheid aan swart mense oorgedra sou wees) is weliswaar verreweg nie gehaal is nie. Die hernieude aandag aan grondhervorming was die gevolg van sowel woelinge in die ANC rondom die posisie en ideologie van die "Zuma"-(of linker-)vleuel van die party, sowel as die kompromielose aandrang van die "Economic Freedom Fighters" of EFF, die party radikaal links van die ANC onder die leiding van die populistiese Julius Malema. Reeds onder leiding van oud-president Zuma, maar veral weens die volgehoue aandrang van Malema binne en buite die parlement, het die ANC by die kongres (Desember 2017) waar mnr Cyril Ramaphosa vir Zuma as leier van die ANC vervang het, ook besluit dat "grondonteiening sonder vergoeding" (OSV) voortaan ANC beleid sou wees.

'n Storm van protes uit die geledere van sowel opposisiepartye regs van die ANC as van die georganiseerde landbou in Suid-Afrika het hierdie aankondiging begroet Nogtans het dit uit'n wye reeks vergaderings waarin lede van die publiek oor die saak gekonsulteer is, geblyk dat 'n beduidende meerderheid Suid-Afrikaners ten gunste van hierdie verwikkeling is. Ten tyde van hierdie skrywe (einde Maart 2019) is daar nog heelwat onsekerheid oor die saak. Dit is byvoorbeeld nie duidelik of die Grondwet wel gewysig moet/sal word ten einde hierdie beleid te akkommodeer nie.

Heelwat kommentators en opposisielede het reeds daarop gewys dat OSV in terme van die voorsieninge van die huidige Grondwet tans wel moontlik is en dat die Grondwet dus nie gewysig hoef te word nie (Joubert 2019; vgl. ook artikels 25 (2) en (3) van die Suid-Afrikaanse Grondwet van 1996). Die bewering word telkens gemaak dat swart mense sonder landboukennis of-vaardighede enersyds nie behoort te (probeer) boer nie, en andersyds waarskynlik nie wil boer nie en finansiële kompensasie bo grond (sal) verkies. Ander kommentatore het reeds gewys op hoe lank die (grond) wetswysigingsprosesse sal neem om afgehandel te word (Du Plessis 2018). Die president staan in sy toesprake (ook in die buiteland) by die aangekondigde beleidsbeginsel, maar suggereer ook meermale dat daar nie ingemeng sal word met produktiewe landbouprodusente en -produksie 
nie, en dat dit eerder onbenutte grond is wat (uit-)gedeel sal word, veral in stedelike gebiede. Talle opponente van die beleid wys op die gevolge van so 'n skuif vir buitelandse beleggings; die argument is dat buitelandse beleggers sal wegskram van Suid-Afrika as die beginsel van eiendomsreg van onroerende bates in die gedrang sou kom.

Ek kan nie in hierdie artikel alle aspekte van die debat, wat tans die koerante oorheers, aan die orde stel nie. Ek keer terug na die vraag i.s. die verstandigheid daarvan vir die kerk, en met name die NG Kerk, om by hierdie debat betrokke te raak. Indien "betrokke raak" "aktiewe leiding neem" of "koers en oplossings aandui" sou beteken, kan ons saamstem dat so-iets sowel ongewens as onmoontlik sou wees. Daar is egter ander maniere waarop die kerk by hierdie saak betrokke sou kon raak, en dit is hierdie alternatiewe wat eerder ons aandag verdien.

Ek wil my bepaal by vier kern-oorwegings wat vir die rol wat die kerk in hierdie kontroversie kan speel, van regstreekse belang is. Dié vier oorwegings is: menswaardigheid, leierskap, moraliteit en dialoog. Die wyse waarop elk van hierdie waarde-oorwegings ter sake is vir die fasiliterende rol wat die kerk in die grondkwessie kan speel, sal hopelik blyk uit die bespreking wat volg.

\section{Menswaardigheid}

Die kerk het in die eerste plek belang by Suid-Afrika se gronddebat omdat 'n sentrale aspek van dit wat in hierdie debat op die spel is, aangedui kan word as 'n strewe na menswaardigheid. Die sorg om grond word deur talle deelnemers aan die debat, veral uit die geledere van swart en arm mense, getipeer as 'n sorg om die herstel van menswaardigheid. Die kerk kan en mag nie onbetrokke bly by so 'n aandrang nie.

Die krisis rondom grond bestaan in hierdie land nie van vandag of gister af nie. Dit het wel akute afmetings aangeneem sedert die president se aankondiging dat onteiening sonder vergoeding nou amptelike regeringsbeleid is. Maar die krisis oor grond se verhaal loop baie verder terug. Dit loop oor die geskiedenis van die sogenaamde "hervestiging" van swart mense tydens apartheid en oor die gru-verhale van die sogenaamde "opruiming" van "swart kolle" en "krotbuurte" soos Distrik Ses en Sophiatown (Vgl. Huddlestone 1956). 'n Sentrale deel van daardie 
geskiedenis is die irrasionele wetgewing van die Unie van SA wat, in 1913, bepaal het dat wit en swart nie van mekaar grond mag koop nie, en wat swart eienaarskap van grond op $10 \%$ vasgepen het, tot dit later opgeskuif is na $13 \%$ (Collins \& Burns 2007). Dit loop terug oor die konflikte van die Groot Trek. (Piet Retief is hier 'n belangrike uitsondering aangesien hy op 'n eerbare manier via 'n geskrewe kontrak grond by Dingaan gekoop of geruil het. Dingaan het die kontrak geïgnoreer en Retief en sy afvaardiging wreed vermoor, soos goed bekend.)

Die geskiedenis loop verder terug oor die onbeheerste besetting van grond deur trekboer-pioniers in die $18^{\text {de }}$ eeu. Hierdie "pioniers" se metode was om die wye, skynbaar onbewoonde veld (al het Khoi en San mense daar rondgeswerf) in te trek en lukraak hartbeeshuisies op te rig en die omringende veld as hul eiendom te beskou. Hier het hulle gewoon totdat die veld kaal bewei was, waarna alles wat kon, weer op waens gelaai is en verder getrek is totdat nuwe weiveld gevind is wat op dieselfde manier beset is (Giliomee 2003: 58-87).

Die geskiedenis gaan, les bes, terug op die eerste kontak van koloniserende Westerlinge soos Jan van Riebeeck en Simon van der Stel met die Khoi en San mense wat vir eeue hul jagterbestaan gevoer het in die omgewing van 'n plek wat, ironies genoeg vir hulle, die naam gekry het van "Kaap die Goeie Hoop".

As ons hierdie geskiedenis, waarvan ek pas slegs 'n paar breë buitelyne in herinnering geroep het, gadeslaan, tree daar een sentrale begrip aan die lig wat die verhaal samevattend interpreteer. Dit is die begrip: Miskenning van menswaardigheid. Tussendeur al die kwetsende woorde, woedende betogings, onbeholpe pogings tot grondbesetting en opruiende politieke retoriek van ons tyd, behoort ons in die pas vermelde gebeure die stemme wat die pyn van die verlies van menswaardigheid verwoord, skerp en helder te hoor. Verstaan my goed: ek probeer op geen manier die wilde retoriek, die onwettige handelinge en die politiek-ekonomiese dreigemente in die hedendaagse debat geringskat of goedpraat nie. Een boodskap is egter sentraal in die verhaal van hierdie konflik: die verlies van grond word beleef as die verlies van menswaardigheid.

Dit bring my ook by die kerk. Die kerk, so blyk dit uit die Belydenisskrifte reeds uit die Twaalf Artikels - is nie in eerste instansie iets wat ons sien nie. 
Die kerk is in eerste en laaste instansie iets wat ons glo - "ek glo aan een heilige, algemene, Christelike kerk". Die kerk in sy institusionele gestalte is daarby nie boere of landbouers of eiendomsontwikkelaars of die bewoners van stedelike woonbuurte nie: al die instansies wat direk of indirek deur huidige verwikkelinge rondom grondhervorming in Suid-Afrika geraak sou kon word nie. Maar waar menswaardigheid in die gedrang is, kan en mag die kerk nie onbetrokke bly nie. Want menswaardigheid is 'n sentrale aspek van dit wat die kerk wel in die wêreld doen, naamlik die verkondiging van die evangelie. Die kerk is nie die Afrikaner- of Zoeloe of Duitse volk nie, maar wel die volk van God. Dis 'n volk, so glo die kerk, wat God self vanuit alle bestaande volke, tale en kulture verkies het om sy beelddraer in die wêreld te wees (Heidelbergse Kategismus).

Dat God soveel feil het vir die mense dat ons vandag kan getuig van die gebeure van Bethlehem, Getsemane, Golgota en die leë graf, is die onomstootlike en onomkeerbare bewys dat daardie God se ander naam Immanuel is - God met ons. Hy doen dit alles om ons ontwil. Dat hy dit doen, verleen aan mense - álle mense, nie slegs wit mense of swart mense, of mans of rykes nie, maar álle mense - waardigheid. Daardie menswaardigheid gee aan alle mense die reg op 'n vol maag, klere vir die liggaam, 'n dak oor die kop, 'n plek waarna ons mag verwys as ons tuiste ("home"), 'n geleentheid om iets met ons lewe te maak wat die moeite werd is. " $U$ het hom [die mens] net 'n bietjie minder as 'n hemelse wese gemaak en hom met aansien en eer gekroon. $\mathrm{U}$ laat hom heers oor die werk van $\mathrm{u}$ hande, U het alles aan hom onderwerp" (Ps 8: 6-7).

Wanneer amptenare dan opdaag met hul aankniplêers en stelle regulasies en mense meedeel dat die plek waar hulle (vir dekades, miskien meer as 'n eeu) tuis was, van hulle weggeneem word, en wanneer stootskrapers begin dreun om dakke wat beskerming gebied het teen die gietende reën en die fel sonlig, plaat te stoot, is dit wat verwoes word nie in die eerste plek 'n karige hopie materiële besittings nie (hoe waardevol daardie hopies ook al vir hul eienaars mag wees). Wat verwoes of weggeneem word, is mense se basiese menswaardigheid - dit wat aan hulle waarde gee in hul eie en ander mense se oё.

Daar is veel te sê oor "waardes" - dié begrip waarvan "menswaardigheid" afgelei word. Wanneer jy egter van "menswaardigheid" praat, is die waarde wat voorop staan, niks anders en niks minder nie as die mens self. Die 
mens is die hoë waarde ter wille waarvan die evangeliegebeure plaasvind. Om daardie waarde te geringskat deur 'n vulgêre miskenning van dit wat aan mense in hul eie en ander se oë waarde verleen, is om die idee van menswaardigheid te minag.

Een van die redes waarom menswaardigheid 'n ontoereikend gewaardeerde waarde in die geskiedenis van die NG Kerk was, is dat die kerk vir dekades, indien nie eeue nie, 'n aversie gehad het van die begrip "humaniteit", of menslikheid. Enigiets wat net geruik het na sogenaamde "humanisme" is verdoem as in stryd met die goeie gereformeerde leer wat die eer van God as die hoogste, absolute en finale waarde beskou het. In die proses is misgekyk dat die openbaring van God waarvan die Bybel en die evangelie getuig, juis die verhaal is van God se bemoeienisse om ons gevalle menslikheid in ere te herstel. God word in die evangelie mens sodat ons self weer waarlik mens kan wees. As ons opkyk na die kruis, sien ons nie alleen die ware God nie, maar veral ook de ware mens. Menslikheid/humaniteit is geen bedreiging vir die evangelie nie; dit spruit voort uit die korrekte verstaan van die evangelie.

Een van die tragedies van die NG Kerk in SA se veelbewoë geskiedenis (en ek beweer geensins dat daardie geskiedenis nie ook vele prysenswaardige momente bevat nie) is hoe lank dit ons geneem het om onder die indruk te kom van die manier waarop die geforseerde, onregmatige verdeling van grond in hierdie land mense se menswaardigheid in die gedrang gebring het. Met die "opruiming" van Sophiatown in die 1950's was die figuur van Trevor Huddlestone, die Anglikaanse priester wat daar gewerk het en sy bekende boek Naught for your comfort (Huddlestone 1956) oor daardie ervaring geskryf het, prominent in die koerante. Het ons ooit enige foto of vertelling van 'n NG predikant gehoor oor bystand in of protes teen 'n onregverdige onteiening van grond in daardie - of 'n later - tyd? Die enigste moontlike uitsondering sou Beyers Naudé wees, en ek is nie eers daarvan seker nie. As dit by protes teen grondvergrype kom, het die NG Kerk, om die minste te sê, 'n onindrukwekkende geskiedenis in SA - selfs 'n afwesige gestalte.

In hierdie verband herinner ek my'n insident wat ek persoonlik meegemaak het. In die vroeë 1980's was ek saam met 'n groep jong dosent-kollegas op 'n besoek aan wat toe nog as "Crossroads" bekend gestaan het - in daardie tyd 'n bekende plakkerskamp aan die buitewyke van Kaapstad. Die amptenaar 
van die betrokke staatsdepartement wat "instromingsbeheer" daardie tyd moes reguleer, het ons toegespreek. Ek het die man eintlik jammer gekry, want sy verhaal was deurspek van wanhoop vanweë die onmoontlikheid van sy en sy kollegas se taak, naamlik om soveel swart mense moontlik in hegtenis te neem en dan op treine te plaas wat hulle sou laat "terugkeer" na hul sogenaamde "tuislande" (in daardie geval Ciskei en Transkei). As dit nie so tragies was nie, was dit eintlik komies om sy verhale aan te hoor van sulke teruggestuurde treinpassasiers wat by die eerste en beste geleentheid - Worcester se stasie - van die trein afgespring het en weer die pad terug Kaap toe aangedurf het. Niemand het beter as daardie amptenaar geweet hoe futiel die destydse beleid van "instromingsbeheer" was nie, ten spyte van die Nasionale regering se hopelose, dog volhardende, uiteindelik blindelingse pogings om sosiale ingenieurswese toe te pas deur mense te probeer rond(ver)skuif soos pionne op 'n skaakbord ter wille van die bereiking van die oogmerke van 'n ideologie (apartheid). ${ }^{2}$ Terwyl hy met ons sit en praat, hoor 'n mens toe voortdurend die getimmer van hammers waarmee mense in die area direk rondom hierdie amptenaar se kantoor, besig gebly het om nuwe strukture op te rig. Ek sal dit nooit vergeet nie toe hy vir ons sê: "Hoor julle die hamerslae -rat-tat-tat ... aanhoudend! Ons hier in die kantoor luister elke dag daarna, en dan sê ons vir mekaar: 'Luister hoe timmer hierdie mense instromingsbeheer in sy $\mathrm{m}^{\star *} \mathrm{r}$ !"'

Diegene van ons wat daar was, het kort daarna 'n brief aan die pers gerig om te pleit vir die einde van instromingsbeheer, sowel as vir, veral, die erkenning dat verstedeliking nie gekeer kan word nie. Ons het ook gevra vir beter beplande informele behuisingsareas waarin daar ten minste strate sou wees waarin 'n mens met voertuie kan ry om vullis te verwyder en dienste te verskaf. Nodeloos om te sê: ons pleidooie het op dowe ore geval. Waarom ek die verhaal vertel, is ook om te beklemtoon dat daar in daardie tyd en omstandighede geen sweem van meelewing van die kant van die

2 In die bekende boek van Paul Johnson A History of the Modern World: from 1917 to the 1980's ('n uitgebreide uitgawe met die total Modern Times het later verskyn) is die enigste Suid-Afrikaanse politieke leier na wie Johnson verwys dr Hendrik Verwoerd, en dit in hoofsaak om aan te toon hoe 'n ekstreme eksponent van "sosiale ingenieurswese" hy was - d.i. die praktyk om mense na willekeur rond te skuif ten einde die doelwitte van 'n ideologie te verwerklik (Johnson 1985: 523). "Instromingsbeheer" in die tyd van Verwoerd en sy twee onmiddellike opvolgers, BJ Vorster en PW Botha, was een van die mees ekstreme vorme van sosiale ingenieurswese in die geskiedenis. 
NG Kerk was nie. En dan praat ons in die huidige krisis van betekenisvolle morele leierskap van die kerk? Die kerk sou sigself gelukkig kon ag as slagoffers van onregmatige grondreëlings die kerk nou skielik ernstig opneem - of daardie slagoffers nou wit of swart is.

\section{Leierskap}

Het die kerk dan geen rol te speel in die huidige grondkrisis in Suid-Afrika nie? Dit sou ek nie sê nie. Die wonder is en bly dat die kerk nog 'n stem het wat mense hoor en op reageer. Die kerk, sou ek wou beweer, kan leierskap verskaf in die huidige krisis. Daaroor vervolgens iets meer.

Dat die kerk "leierskap" in ons huidige krisis kan of moet bied, moet reg verstaan word. Leierskap beteken normaalweg 'n tipe van handeling waar mense in 'n nie-egalitêre verhouding tot mekaar staan, en die een (groep of individu) dermate invloedryk is of word dat hy/sy/hul voorkeure deur die ander (die sogenaamde "volgelinge") erken en aanvaar word. Sodanige leierskap veronderstel meesal een of ander (semi-) politieke konteks, d.i. 'n konteks waarin dit gaan om die bedinging van samelewingsbronne of -voordele (vgl. Lasswell 1990).

Ek bly skepties oor kerklike leierskap in laasgenoemde sin. Die leierskap wat die kerk oor die grondkwessie kan bied, is myns insiens veel eerder 'n geval morele as van politieke leierskap. Kerklike "leierskap" kan nie 'n kwessie wees van die opdring van 'n posisie aan mense wat eers anders gedink en gehandel het nie. Alvorens ek iets meer sê oor morele leierskap, is daar in hierdie verband 'n ander onderskeiding t.o.v. leierskap wat van waarde is. Dit is die onderskeiding tussen transaksionele en transformatiewe leierskap. In transaksionele leierskap behels leierskap 'n soort transaksie tussen leier en volgelinge. Leiers benader volgelinge met die oog daarop om iets vir iets anders te ruil: werkgeleenthede vir stemme of subsidies vir politieke veldtogbydraes. Dis leierskap met 'n "quid pro quo" logika.

Daarteenoor staan transformatiewe leierskap. Hier gaan dit om die volronde erkenning en reaksie op 'n bestaande behoefte of eis van potensiële volgelinge. Dit gaan ook daarom om werklik op die uitkyk te wees vir persoonlike motiewe in volgelinge, om aan belangriker behoeftes te probeer voldoen en om by die volle persoon van die volgeling betrokke te probeer raak. Die gevolg van hierdie soort leierskap is die totstandkoming 
van 'n verhouding van wedersydse vertroue, stimulasie en funksionering op 'n hoër vlak, met die effek dat volgelinge self leiers word, en dat leiers morele agente word. Dit is 'n soort leierskap wat mense ontwikkel, eerder as om hulle te beheer.

As die kerk 'n rol het om te speel op de terrein van (veral morele) leierskap, sien ek dit nie as leierskap in die sin van vooruit stap, voorskrifte uitdeel en 'n self-geformuleerde bloudruk op sake afforseer nie. Die beste leiding wat die kerk kan help gee, is die leiding wat lei tot volgelinge wat self leiers word. Sulke leiers ontwikkel self die program wat die probleem wat hulle konfronteer, kan benader. Hulle ontwikkel hulself en hul leierskap deur 'n proses van dialoog. Daaroor handel ek later in veel meer besonderhede.

\section{Moraliteit, waardes en morele leierskap}

In hierdie stadium moet ons die relevansie bespreek van die derde kategorie waarna aan die begin verwys is as 'n aspek van die rol wat die kerk in hierdie land se gronddebat kan en behoort te speel. Hierdie kategorie is moraliteit. Dit is sinvol om nou eers oor moraliteit 'n paar opmerkinge te maak, want dit bring beter insig in die aard van morele dilemmas. Die grondvraagstuk in Suid-Afrika verteenwoordig naamlik 'n yslike morele dilemma. Wat bedoel ons daarmee?

Moraliteit is die (waarneembare/aantoonbare) verskynsel wat ons in alle kulture aantref, naamlik dat mense hul gedrag onderwerp aan 'n behorenseis, met ander woorde dat hulle erken dat die "behoort"-vraag oor reg en verkeerd/goed en kwaad ten opsigte van alle vorme van menslike gedrag gevra kan word (vgl. Wallace \& Walker 1970). Etiek, soos ek dit verstaan, is daarenteen die uitkoms van 'n soort intellektuele besinning; dit is 'n onderafdeling van die filosofie en/of teologie. Etiek is die poging om deur te druk na maniere hoe ons oordeelsvorming op morele vlak kan bereik. Dit identifiseer modelle van morele oordeelsvorming, soos konsekwensialisme, reël-moraliteit en deugde-etiek, ondersoek krities of en hoe effektief hierdie verskillende benaderings is vir die proses en resultate van morele beoordeling, en ondersoek alternatiewe of nuwe benaderings in dieselfde verband (vgl. Welman 1975 en Rachels \& Rachels 2010).

Etiek is iets wat 'n mens rustig in jou studeerkamer of in die lesinglokaal kan bestudeer of beoefen, soms ook oor 'n lang tyd (Vgl. Shafer-Landau 
2007). Maar soms het jy min tyd, want jy word gekonfronteer deur morele dilemmas wat vra om dringende en spoedige oplossings. Dan het ons nie slegs maar met etiek in die algemeen te make nie, maar met toegepaste etiek (vgl. Byvoorbeeld Winker \& Coombs 1993, asook Brody 1983.)

'n Morele dilemma is 'n probleem van 'n morele aard waar daar van meet af aan twee opsies is wat skynbaar ewe geldig is, waar die kies vir die een moontlikheid die aanvaarding van die ander uitsluit en waar watter keuse ook al uitgeoefen word, moreel is; dit gaan m.a.w. in so 'n morele dilemma nie om 'n morele teenoor 'n immorele moontlikheid nie; albei moontlikhede doen hulself voor as morele keuses.

Dit bring ons terug by ons oorkoepelende onderwerp. In hierdie artikel gaan dit om die kerk se rol in die benadering tot en die oplossing van 'n enorme morele dilemma - 'n dilemma so problematies en uitdagend dat ons gans onseker is oor selfs net hoe om te begin om daaroor te dink. Die dilemma is: Hoe gaan ons by 'n model vir grondherverdeling uitkom wat voormalige onreg sover moontlik regstel sonder om die ekonomie (met name die landbou) in die proses ernstig te skaad of selfs te vernietig?

Indien die kerk hieroor leierskap wil bied, dan is dit nie die soort leierskap wat hierbo transaksioneel genoem is nie. Die leierskap wat hier ter sake is, is morele leierskap. Morele leierskap is daardie vorm van leierskap wat die vestiging en ontwikkeling van 'n waarde-kultuur op die oog het.

Wat is waardes? Johannes Degenaar definieer 'n waarde by geleentheid as volg: "A value is a differential, regulative principle of organisation that indicates desirability and that functions normatively in the reflection, judgements, decision-making processes and actions of people" (Degenaar 1986: 103-104). Rokeach voeg hieraan toe: "Values function as standards or principles in that they guide our decisions concerning how to act and in that they can be used to justify or legitimise our decisions and actions. A set of values or a value system of a person or group is an enduring organisation of values along a continuum of relative importance" (Rokeach 1973: 5).

Ons sou, kortom, kon sê dat waardes gedefinieer kan word as ons ons belangrikste en mees duursame oortuigings ("beliefs") - daardie oortuigings wat ons handelinge beïnvloed met 'n durende krag en effek. Waardes is daardie oortuiginge waarvan ons die sterkste oortuig is en 
wat 'n fundamentele invloed uitoefen op ons lewensbeskouing en die lewenstrategie wat ons kies ten einde sin in ons lewens te vind.

In 'n multikulturele samelewing soos dié in Suid-Afrika, ervaar ons deurgaans die moontlikheid en werklikheid dat ons te make het met konflikterende waardesisteme. Dit is juis wat die Grondwet van 1996 so merkwaardig maak as 'n kultuur- en waardeskeppende dokument. Daardie Grondwet het tot 'n beduidende mate daarvoor gesorg om 'n ooreenkoms ("settlement" is 'n beter woord) te vestig oor'n stel waardes (veral uitgedruk as "regte") waarmee die meeste Suid-Afrikaners kon identifiseer en wat in die Grondwet verskans is. Soos ek die reaksies van die hoofstroom kerke in Suid-Afrika op die Grondwet verstaan, is hulle meesal akkoord met daardie waardes. Daarom, sou ek wou redeneer, bestaan die vernaamste uitdaging wat tans aan die kerke gestel word ten opsigte van morele leierskap, wat hulle kan en behoort uit te oefen, juis daarin om die waardes van die Grondwet te koester en te propageer.

Die Grondwet is weliswaar nie die laaste woord oor ons waardes nie. Dit ondervang nie alle oortuiging wat vir alle Suid-Afrikaners belangrik is nie. Die waarde van die Grondwet is egter dat dit 'n instansie was van 'n merkwaardige en kosbare progressiewe ooreenkoms (weer: ek verkies die sterker Engelse woord "settlement") deur middel waarvan ons as SuidAfrikaners vir mekaar kon sê: "Al stem ons nie oor alles saam nie, en al is daar steeds kwade gevoelens - selfs woede - oor die onreg van die verlede, kan ons nogtans vir eers hier tydelik tot stilstand kom omdat ons 'n basis gevind het waarop ons die eerste mure van 'n nuwe samelewing in hierdie land gaan probeer bou". Dit beteken nie dat die fondasie van die Grondwet onfeilbaar is of nooit krake sal toon nie. Een of ander tyd sal ons die "settlement" van 1994 weer in oënskou moet neem en bes moontlik veranderinge moet aanbring om die meer gewigtige strukture wat ons daarop wil baseer, effektiewer te kan dra. Maar Rome (of Suid-Afrika!), so sê die spreekwoord tereg, is nie in 'n dag gebou nie. Ons Grondwet bied genoeg steun om die eerste tentatiewe mure van ons nuwe leefwêreld staan te maak.

Die gronddebat van ons tyd is bes moontlik 'n aanduiding dat talle waarskynlik die meerderheid - Suid-Afrikaners ernstige vrae begin vra oor die huidige Grondwet se bepalings oor eiendomsreg. In ons huidige Grondwet word eiendom nie positief as 'n reg beskou nie, maar word 
bloot bepaal dat eiendom nie van iemand weggeneem kan word sonder behoorlike vergoeding nie (artikel 25, (1)). In artikels 25, (2) en (3), word daar dan inderdaad voorsiening gemaak vir die onteiening van eiendom en die basis vir vergoeding daarvoor. Onderafdeling 5 bepaal dat die staat redelike stappe moet doen om aan mense toegang tot grond te bied. Die laaste twee subartikels van artikel 25 bespreek dan stappe wat gedoen kan en moet word om die onreg van die verlede te probeer regstel wat betref grondbesit. Die huidige debat oor grond handel in hoofsaak oor artikel 25, subartikels (2) en (3).

\section{Dialoog}

Die kerk, so het ek vroeër geredeneer, kan leierskap bied in hierdie dispuut, solank daardie leierskap die karakter aanneem van morele, transformatiewe leierskap. Hoe sou de kerk te werk kon gaan om daardie leierskap nie alleen uit te oefen nie, maar so te operasionaliseer dat dit positiewe effekte in ons situasie kan hê?

My voorstel is dat ons slegs vordering sal maak t.o.v. hierdie saak as ons dialogies te werk gaan. Die laaste deel van hierdie artikel is daarom in hoofsaak 'n analise van die begrip en verskynsel van dialoog. Oor dialoog is daar wel heelwat te leer, nie soseer in die Bybel nie, maar wel by die ou Grieke, en met name by Sokrates, die vader van die filosofie. Dialoog is die proses wat 'n mens lei tot verdiepte insig wat die moeite werd is. Dialoog handel oor'n saak, en in SA is daardie saak tans die eenvoudige vraag: Hoe gaan ons by 'n model vir grondherverdeling uitkom wat voormalige onreg sover moontlik regstel sonder om die ekonomie (met name die landbou) in die proses te vernietig?

Vir Sokrates ${ }^{3}$, by wie ons die meeste oor die aard van dialoog kan leer, begin egte dialoog by die erkenning van wat bekend staan as die docta ignorantia, die erkenning, aan die kant van alle deelnemers en alle partye in die kwessie, dat hul kennis van 'n moontlike oplossing beperk is (Sokrates sê: "al wat ek vir seker weet, is dat ek niks weet nie!") Ons tree toe tot

3 Hans-Georg Gadamer, die bekende hermeneutiese filosoof vir wie interpretasie fundamenteel 'n dialogiese proses is, se analise van Sokratiese dialoog is een van die bestes wat bestaan. Vgl. sy 1960: 172-185. Vgl. ook G Warnke se interpretasie van Gadamer oor Sokratiese dialoog in Warnke 1987: 100-106. 
die dialoog omdat ons iets by mekaar wil leer. Ons tree in dialoog, nie in debat nie, want in 'n debat, het 'n mens reeds 'n standpunt en probeer jy teen elke prys en met alle middele tot jou beskikking, jou standpunt op jou teenparty afdwing. 'n Dialoog werk anders. In 'n dialoog stel jy jouself oop vir die insigte van jou teenparty; jy is bereid om van hom/haar te leer. ${ }^{4}$ Natuurlik is jy ook krities; dit help nie om die ander te volg as sy/haar paadjie uiteindelik bestem is om oor die afgrond te loop nie.

Die belangrikste aspek van 'n dialoog is egter die feit dat, indien die interaksie slaag, albei partye 'n insig bereik wat hulle nie aanvanklik gehad het nie. Hegeliaans uitgedruk: die sintese, wat die antitese opgeroep het, word opgehef (aufgehoben) in 'n hoëre sintese. In die sintese of uiteindelike gevolgtrekking word iets behou van die geldige insette van albei partye deur die loop van die gesprek, maar'n nuwe, hoër insig word tog uiteindelik bereik.

My punt is die volgende: Dialoog, as die metode van 'n transformatiewe morele leierskap, bied die sleutel tot die aanpak van die morele dilemma wat vroeër geïdentifiseer is. Let weer daarop waarom ek soveel klem plaas op die morele dilemma-karakter van die kwessie. Aan die een kant vind ons die oënskynlik moreel geregverdigde verwyt dat mense ernstig te na gekom is in SA se geskiedenis van grondverdeling. Vandag besit wit mense sowat $70 \%$ van die land se bewerkbare of benutbare landbougrond, selfs na die onlangse oordragte. Om hierteen te protesteer en aan te dring op regstelling, is moreel volkome verstaanbaar.

Die dilemma waarvan ek praat, het egter ook te make met die ander kant van die saak. Dit is die aanspraak van die oorgrote meerderheid gevestigde kommersiële boere dat hulle geen grondstelers in hul eie leeftyd was nie, dat talle van hulle nie hul grond van vorige geslagte geërf het nie, maar ten duurste via (Land-)banklenings bekom het, dat hulle oor dekades enorm veel in hul grond belê het, dat hul produksie onontbeerlik is met die oog op die land se voedselsekerheid, dat, indien grond aan mense gegee moet word, daar eerstens na die groot hoeveelheid staatsgrond gekyk moet word (in sowel landelike as stedelike gebiede), dat die verhale van nuwe boere

4 Dit word meermale beweer dat die ontdekking - onder leiding van Sokraties, teenoor die Sofiste - van die verskil tussen debatte en dialoog in antieke Griekeland in wese ook die begin van Westerse filosofie was. Vgl. Vir hierdie argument Van Niekerk 2006. 
se mislukkings om die mas op te kom duidelik illustreer hoe 'n uiters gesofistikeerde en komplekse bedryf hedendaagse landbou geword het en hoe klein 'n mens se kans is om grond suksesvol en winsgewend te bewerk. Les bes verklaar hierdie gevestigde boere hulself feitlik deurgaans bereid om, via die georganiseerde landbou, nuwe toetreders tot die landbou sover moontlik op te lei en touwys te maak.

Let daarop dat albei posisies wat ek pas kursories geskets het, nie alleen in betekenisvolle opsigte waar is nie, maar dat albei aansprake ook moreel geregverdig is. Al uitweg uit hierdie dilemma is die praktyk van dialoog. Dialoog is die vog wat die harde kors van onversetlikheid en selfregverdiging in hierdie opposisie kan vermurwe tot by die punt waar ons genoeg aanpasbaarheid, soepelheid en wedersydse begrip verwerf het om te verseker dat ons nie slegs téénoor mekaar staan nie, maar werklik ná mekaar begin luister en ván mekaar begin leer.

Nou is dit teoreties natuurlik baie maklik om te pleit vir dialoog as 'n mens werk met die aanname dat die partye wat aan daardie dialoog deelneem, dadelik beskikbaar en gereed is om die gesprek te begin. Die saak is uiteraard veel meer gekompliseerd as dit. Nie alleen praat die aanspraakmakers op grond nie almal uit dieselfde mond nie, maar ook die georganiseerde landbou kom my meermale voor as gefragmenteer en onwennig in eie geledere. Waar en hoe begin ons?

My antwoord daarop is dieselfde as die antwoord op die vraag hoe dien ek en is ek goed vir my naaste, soos die Bybel onverbiddelik vereis. Niemand kan ineens iets doen wat al die probleme in die wêreld kan oplos nie. As ek lyding wil verlig, moet daardie lyding by voorkeur eers 'n gesig, 'n individuele identiteit vir my kry. Ek help soveel makliker en soveel beter vir iemand wie se naam ek ken en wie se behoeftes nie net op sy skouers lê nie, maar ook op myne.

Kortom, as ons dialoog wil voer, moet ons begin by diegene vir wie ons ken en met wie ons al 'n pad gestap het. Daarin lê die enorme potensiaal van 'n "grondberaad". Ons ken mekaar, en ons ken die werkers op ons plase en in ons huise. Die gesprek begin met hulle. Soos in 'n egte dialoog, is daar geen waarborg dat daardie gesprek sal uitloop op 'n volmaakte oplossing nie. Dit sal egter enorme wins wees indien ons, as uitkoms van die gesprek, 'n nuwe gedeelde insig verwerf - 'n insig wat kan dien as die lanseerplatform van 
'n volgende en 'n verdere volgende gesprek - 'n gesprek, soos ek voorsien het, wat nie van een kant af beheer word nie, maar wat die deelnemers bemagtig om, op basis van die vertroue wat die dialoog skep, volgelinge te transformeer tot leiers wat uiteindelik oplossings kan vind.

\section{Samevatting en gevolgtrekking}

In hierdie artikel het dit gegaan oor die wenslikheid en sinvolheid daarvan dat die kerk op een of ander wyse betrokke raak by die teenswoordige (2019) debat oor grondhervorming (met name onteiening sonder vergoeding) in Suid-Afrika. $\mathrm{Na}$ 'n kontekstualisering van die oorsprong van hierdie stuk, is die wenslikheid van kerklike betrokkenheid onder die noemer van vier kern-oorwegings bespreek, naamlik menswaardigheid, leierskap, moraliteit (waaronder waardes en morele leierskap te berde gebring is) en dialoog as die sleutel-"metode" om by die gesprek betrokke te raak sowel as dit wat in die interaksie tussen rolspelers gefasiliteer moet word.

Die verlies van grond deur swart mense in Suid-Afrika word deur hulle beleef as 'n aantasting van hul menswaardigheid, ongeag die vraag of die herstel van (veral landbou) grondbesit sal uitloop op 'n produktiewe bewerking en benutting van die grond. Menswaardigheid is 'n sleutelbegrip in die verkondiging van die evangelie. Daarom moet die kerk sigself sorge maak oor hierdie saak, veral omdat menswaardigheidsoorwegings in die verlede van (veral) die NG Kerk skromelik afgeskeep is. Dit hang ten nouste saam met die geringskatting van die belang van die waarde van humaniteit in die interpretasie van die evangelieboodskap.

Tweedens kan die kerk die grondgesprek fasiliteer in 'n leidinggewende hoedanigheid. In so 'n geval moet die begrip "leierskap" egter reg verstaan word. Dit gaan nie in hierdie soort leierskap om 'n transaksionele verhouding waarin die wil van die leier op volgelinge afgedwing word nie. Dit gaan eerder of transformatiewe leierskap waarin mense ontwikkel word om self leiers te word en gesamentlik na konsensus te soek.

Die soort leierskap wat die kerk by voorkeur moet bied, is daarby, in die derde plek, morele leierskap. Dit spruit voort uit insig in die aard, omvang en kompleksiteit van die grondkwessie in Suid-Afrika. Dit is leierskap wat 'n waardesisteem in die land moet beding en fasiliteer. Die betekenis van die begrip "waardes" word geanaliseer, en daar word aangetoon hoe die 
Suid-Afrikaanse Grondwet 'n progressiewe, dog onvoltooide konsensus ("settlement") verteenwoordig wat 'n platform bied vir latere herbesinning en voortgang in die debat oor die grondslae van 'n waarde-bemiddelde samelewing in Suid-Afrika.

Die "hoe" van die kerk se betrokkenheid word in hoofsaak ondervang deur die begrip "dialoog", soos teoreties begrond in die Sokratiese model. In die betoog word 'n pleidooi gelewer dat genoemde dialoog nie uit die lug val nie en dat die sukses daarvan nie gewaarborg kan word nie, veral as dit moet 'n aanvang neem sonder die bestaan en ontwikkeling van 'n vertrouensverhouding tussen die deelnemende partye nie.

Ek sluit af deur opnuut te verwys na die aanhaling van Frederick Douglas ${ }^{5}$ wat as motto vir die artikel gekies is: Where justice is denied, where poverty is enforced, where ignorance prevails, and where one class is made to feel that society is an organized conspiracy to oppress, rob and degrade them, neither persons not property will be safe. Die gronddebat in Suid-Afrika sal nie weggaan nie, en die kerk sal sy roeping versaak as hy nie betrokke raak by ' $n$ kwessie wat van soveel belang is vir die meerderheid van hierdie land se mense nie. Terwyl talle voorheen veronregte Suid-Afrikaners met die verwagting leef van iets van 'n herstel van vroeëre waardigheid en voorspoed, is die gevaar net so groot dat die debat kan ontaard in 'n mislukking, en dat wantroue, onreg, onkunde en degradasie - al die dinge waarteen Douglas ons waarsku - die laaste woord mag hê.

Die kerk behoort alles in sy vermoë te doen om dit te vermy, en om te streef na die visioen van die profeet Jeremia wat by geleentheid die oënskynlik irrasionale opdrag van God ontvang om grond te koop in Anatot, ten spyte van die wanhopige vooruitsig van die ballingskap:

So sê die Here: Soos Ek hierdie groot ramp oor hierdie volk gebring het, so sal Ek ook al die goeie wat ek hulle beloof het, na hulle toe bring. Daar sal weer grond gekoop word in hierdie land waarvan julle sê: Dit is verower, sonder mens of dier, oorgegee in die mag

5 Douglas was in die middel van die $19^{\text {de }}$ eeu 'n slaaf in die suide van die VSA wat daarin geslaag het om reeds voor die burgeroorlog van 1861-1865 sy vryheid te verwerf. Hy het 'n leidinggewende rol gespeel in die slawegemeenskap, ook na president Lincoln se vrystelling van die slawe in 1863 , en is bekend vanweë talle geskrifte wat hy nagelaat het. 
van die Galdeërs. Grond sal vir silwer gekoop word, kontrakte sal geskryf word met seëls daarop en getuies daarvan (Jeremia 32: 42-44).

\section{Bibliografie}

Brody, B. 1983. Ethics and its applications. San Diego: Harcourt.

Collins, RO \& Burns, JM. 2007. A history of Sub-Saharan Africa. Cambridge: Cambridge University Press.

Degenaar, JJ. 1986. Waardes in die taalspel van die filosofie. South African Journal of Philosophy, 5 (4): 103-110.

Du Plessis, E. 2018. Grondonteiening: kan ons saamstaan? Die Burger (By), 24 November 2018: 8.

Gadamer, H-G. 1960. Wahrheit und Methode. Tübingen: JCB Mohr.

Giliomee, H. 2003. The Afrikaners: biography of a people. Cape Town: Tafelberg.

Huddleston, T. 1956. Naught for your comfort. London: William Collins Sons \& Co.

Johnson, P. 1985. A history of the modern world: from 1917 to the 1980's. London: Weidenfld and Nicolson.

Joubert, J-J. 2019. Onteiening: daar is gronde vir hoop. Die Burger, 13 Februarie 2019: 7.

Juta's Statute Editors. 2003. The Constitution of the Republic of South Africa.

Lasswell, HM. 1990. Politics: who gets what, when and how. New York: Peter Smith Publishers.

Rachels, J \& Rachels, S. 2010. The elements of moral philosophy. Boston: McGraw-Hill.

Rokeach, M. 1973. The Nature of Human Values. New York: The Free Press Shafer-Landau, R. (ed.) 2007. Ethical theory. Oxford: Blackwell. 
Van Niekerk, AA. 2006. “The unexamined life is not worth living”: Socratic dialogue versus Sophist debate at the birth of philosophy. Tydskrif vir Christelike Wetenskap (Festschrift for DFM Strauss), (ISSN 1013-1116)

Wallace, G \& Walker, ADM. 1970. The definition of morality. London: Methuen.

Warnke, G. 1987. Gadamer: hermeneutics, tradition and reason. Cambridge: Polity Press.

Wellman, C. 1975. Morals and ethics. Glenview, Illinois: Scott, Foresman \& Co.

Winkler, ER \& Coombs, JR. 1993. Applied Ethics: a reader. Oxford: Blackwell. 